Izabela Czerniejewska

ORCID: 0000-0001-7575-4876

Uniwersytet im. Adama Mickiewicza w Poznaniu

e-mail: izabela.czerniejewska@gmail.com

\title{
Zakotwiczanie się. Migrantki z Polski w norweskim przedszkolu ${ }^{1}$
}

\section{Summary}

\section{Anchoring. The migrant women from Poland in kindergarten in Norway}

Based on participant observation and ethnographic interviews with Polish women working in kindergartens in Norway, this article studies the migrant women's employment trajectories, including adaptation processes in the workplace and integration into the wider Norwegian society. In this paper, I aim at answering the following questions: How do Polish migrant women go about seeking employment in Norwegian kindergartens? How do they adapt to the new work environment? How do they deal with cross-cultural differences in childcare? How did they learn new norms and values within the institutional context of kindergartens? The research indicates that employment in kindergartens was not merely a way to provide for one's livelihood, but was also a mechanism to establish and develop a closer relationship with members of the Norwegian society, a tool facilitating meaningful connections with the new country.

Keywords: migration, Norway, employment, kindergarten, adaptation

Słowa kluczowe: migracje, Norwegia, praca, przedszkole, adaptacja

\section{Wstęp}

Polacy od pokoleń opuszczali miejsce zamieszkania w poszukiwaniu pracy i lepszych warunków życia, natomiast kierunki i intensywność migracji zagranicznych zmieniały się w zależności od czynników politycznych i ekonomicznych. Po wejściu Polski do Unii Europejskiej i otwarciu granic dostępne stały się rynki pracy w krajach sąsiadujących (Grabowska-Lusińska, Okólski 2009). Od dekady Norwegia jest dla Polaków jednym z atrakcyjniejszych kierunków migracji. Początkowo wyjeżdżali mężczyźni podejmujący prace fizyczne, z czasem dołączały także kobiety pracujące w firmach sprzątających, gastronomii i w hotelarstwie (Napierała, Travena 2010; Friberg 2012; Pawlak 2015). Wraz ze zwiększającą się liczbą Polaków osiedlających się w norweskich miastach zjawiskiem tym zainteresowali się badacze i badaczki.

\footnotetext{
1 Artykuł powstał w wyniku realizacji projektu badawczego nr 2014/14/M/HS3/00842 finansowanego ze środków Narodowego Centrum Nauki.
} 
Prowadzone dotychczas badania skupiały się na wielu aspektach związanych z integracją migrantów w norweskim społeczeństwie oraz ich funkcjonowaniu w różnych przestrzeniach życia społecznego i zawodowego (Napierała 2008; Czapka 2010; Bell, Erdal 2015; Slany, Strzemecka 2015; Gmaj 2016, 2018; Huang i in. 2016; Pawlak 2016). Część z tych badań dotyczyła adaptacji uczniów z Polski do norweskiego kontekstu edukacyjnego (Ślusarczyk, Nikielska-Sekuła 2014; Strzemecka 2015; Ślusarczyk, Pustułka 2016), ale tylko nieliczne prace skupiały się na procesie adaptacji dzieci lub ich rodziców w środowisku przedszkolnym (Czerniejewska, Main 2019). Tymczasem część migrantek nie tylko odwiedza przedszkola, przyprowadzając do nich dzieci, lecz także znalazła zatrudnienie w tych instytucjach. W niniejszym artykule staram się uzupełnić tę lukę, przybliżając sytuację tej specyficznej grupy migrantek z Polski, które podjęly pracę w norweskich przedszkolach. Interesuje mnie nie tylko samo rozpoczęcie przez nie pracy, lecz także proces przystosowywania się, sposoby „zakotwiczania się” w społeczności norweskiej przez zatrudnienie się w instytucji opiekuńczej i edukacyjnej. Otrzymanie pracy było dla moich rozmówczyń celem samym w sobie ze względów ekonomicznych. Zatrudnienie w przedszkolu było też dla nich sposobem ułatwiającym nawiązanie i budowanie relacji ze społecznością norweską, swoistym narzędziem wiążącym je z nowym krajem.

Celem artykułu jest znalezienie odpowiedzi na pytania: Jakie działania kobiety z Polski podejmują, by rozpocząć pracę w norweskim przedszkolu? W jaki sposób przystosowują się do pracy w nowym środowisku? Jak sobie radzą z polsko-norweskimi różnicami kulturowymi w podejściu do opieki nad dziećmi? W jaki sposób uczą się nowych norm i wartości w kontekście pracy z dziećmi w tej instytucji?

Projekt badawczy „Mobilne życia, niemobilne przestrzenie? Migracje kobiet między Polską a Norwegią" realizował zespół antropologów w latach 2016-2018. Dotyczył on różnych aspektów polskiej migracji do Norwegii, m.in. feminizacji migracji, ścieżek zawodowych Polek, wpływu migracji kobiet na rodziny. Podczas badań prowadzonych wśród Polek w Norwegii temat przedszkoli ujawnił się przy okazji rozmów o adaptacji dzieci do środowiska szkolnego i przedszkolnego. Kobiety często opowiadały o funkcjonowaniu przedszkoli i różnicach kulturowych z perspektywy rodziców wychowujących dzieci w Norwegii. Jednak wątek ten znacznie się rozwinął dzięki rozmowom z kobietami, które pracowały w przedszkolach i stał się swoistym studium przypadku.

Część migrantek udzieliła wywiadu dwukrotnie w rocznym odstępie czasu, co umożliwiło pogłębienie refleksji na temat ich pracy. Na potrzeby artykułu analizie poddano 12 wywiadów etnograficznych, opisujących doświadczenia Polek, które pracowały lub nadal pracują w norweskich przedszkolach. Z 6 kobietami wywiad przeprowadzony był dwukrotnie. Była to grupa mocno zróżnicowana pod względem długości pobytu w Norwegii (od 1,5 roku do 10 lat), zatem ich drogi - życiowe i zawodowe - także były różnorodne. Badania prowadzono w Oslo i okolicach, Bergen i Kristiansund. Uzupełnieniem wywiadów były obserwacje uczestniczące w środowisku, w którym kobiety żyją i pracują, w tym wizyty w 6 przedszkolach. 


\section{Ścieżki kariery w norweskim przedszkolu}

W norweskich przedszkolach Polki mogą podjąć pracę na jednym z dwóch stanowisk: asystentki (norw. assistent) lub nauczycielki prowadzącej oddział (norw. pedagogiskleder). Asystentka pracuje z dziećmi, pełni funkcję pomocniczą. Nauczycielka jest odpowiedzialna za kierowanie grupą przedszkolną i wspieranie pracy asystentów. Osoba zatrudniona na stanowisku asystenta nie musi mieć wyższego wykształcenia pedagogicznego, które z kolei jest wymagane od nauczyciela prowadzącego oddział. W większości przedszkoli w każdym oddziale zatrudniony jest jeden nauczyciel i co najmniej dwóch asystentów. W sytuacji braków kadrowych powszechny jest system zatrudniania pracowników wykonujących pracę „na zastępstwo” (norw. vikar). Większość przedszkoli ma takich pracowników w zespole. Popularną odmianą tej formy pracy jest „zastępstwo na telefon” (norw. ringevikar), co oznacza, że pracownik może być telefonicznie poproszony o pracę danego dnia, w określonych godzinach. Obie formy, traktowane przez migrantki jako przejściowe, zwykle były im proponowane w początkowym okresie pracy.

Praca w norweskim przedszkolu jest uważana przez Polki za „dobrą na początek”. Nie postrzegają jej jako fizycznej, co dla wielu rozmówczyń miało ogromne znaczenie w decyzji o jej podjęciu, ponadto relatywnie łatwo ją dostać. Jeszcze kilka lat temu można było otrzymać posadę asystentki w przedszkolu praktycznie bez znajomości języka norweskiego. Od 2018 roku, żeby pracować w przedszkolu lub szkole, należy zdać egzamin na poziomie B2. Mieszkająca w Oslo Krysia (7 lat) ${ }^{2}$ tak wspomina ten czas:

Jak żeśmy tu przyjechali, to był mój pomysł, że szukać pracy w przedszkolu, bo tu jest bardzo łatwo znaleźć pracę w przedszkolu, nie trzeba mieć żadnych kwalifikacji. Trzeba mieć skończone tylko gimnazjum, żeby jako asystent w przedszkolu dostać pracę. Więc ja wtedy bez znajomości języka dostałam tę pracę w przedszkolu.

Praca ta - zdaniem rozmówczyń - daje również szansę na rozwój zawodowy. Wszystkie kobiety, z którymi rozmawiałam, posiadały wyższe wykształcenie, część z nich skończyła kilka specjalizacji. Badane wielokrotnie powtarzały, że jeśli nostryfikują dyplom studiów pedagogicznych polskiej uczelni i zdobędą kilkuletnie doświadczenie zawodowe, mogą się ubiegać o stanowisko nauczycielki prowadzącej oddział.

Jednym z najczęstszych sposobów rozpoczęcia pracy w norweskim przedszkolu było dla rozmówczyń otrzymanie wsparcia przez Norweski Urząd Pracy i Opieki społecznej (NAV). Instytucja ta prowadzi m.in. kursy zawodowe i językowe dla migrantów, które są łączone z praktykami zawodowymi. Kobiety doceniały je z kilku powodów: 1 . był to dla nich intensywny kurs języka norweskiego, sprofilowanego zawodowo; 2. miejsce praktyk było potencjalnym miejscem zatrudnienia, a zatem kurs realnie otwierał ścieżkę kariery; 3. za uczestnictwo otrzymywały ekwiwalent pieniężny, co dla wielu stanowiło znaczny wkład w domowy budżet. Ewa (1,5 roku), która dostała się na taki kurs, przyznaje:

\footnotetext{
2 Imiona respondentek zostały zmienione. W nawiasie podany jest czas pobytu w Norwegii (pierwszy wywiad).
} 
Przez 10 tygodni wałkują ci słownictwo związane z pracą w przedszkolu, nie ma szans, żebyś nie zrozumiała, i jeżeli będziesz ambitna i wyciągniesz z tego kursu, ile chcesz, to dasz sobie radę.

Olga (4 lata), która swoją karierę zawodową w Norwegii rozpoczęła od sprzątania po pracach remontowych, kurs w NAV traktowała jako przywilej:

Ten kurs kończył się praktykami dwumiesięcznymi, na początku to było 3 dni na praktyce, a 2 dni w szkole [na kursie]. Ostatni miesiąc byłam codziennie na praktyce, 8 godzin w pracy. Genialna rzecz. Za cały ten kurs płacił mi NAV. To było troszeczkę mniej niż to na tym sprzątaniu. Było to 6000 [koron] miesięcznie.

Osoby, z którymi rozmawiałam, traktowały zaproszenie na kurs NAV jako okazję do wejścia na norweski rynek pracy, były zadowolone, że mogą skorzystać z takiego ułatwienia.

Kolejnym etapem stawania się pracowniczkami norweskich placówek były według rozmówczyń praktyki zawodowe w przedszkolach. Zwykle trwały one cztery tygodnie, niekiedy były przedłużone, a w niektórych sytuacjach nowicjuszkom proponowano inną formę praktyk. Rozmówczynie miały świadomość, że przedszkola chętnie je przyjmują na praktyki, gdyż są one opłacane ze środków NAV. Jednocześnie podkreślały, że dla nich taka praktyka była szansą, żeby otrzymać dalsze zatrudnienie w miejscu, w którym już się sprawdziły.

Niezmiernie ważnym momentem w początkowym etapie praktyk było spotkanie na drodze zawodowej nieformalnej przewodniczki, wprowadzającej w pracę w przedszkolu. Zwykle to była osoba z dłuższym stażem pracy, której zależało na kontakcie z nową pracowniczką. Kobiety bardzo doceniały rolę swoich mentorek, traktowały je ,jak guru”, niektóre wręcz uważały, że to właśnie dzięki nim tak wiele osiągnęły w życiu zawodowym. Olga (4 lata), z wykształcenia pedagog, mówi:

I przygarnęła mnie Barbara. Ona pracuje w przedszkolu 27 lat albo więcej, ma ogromne doświadczenie i jest fantastyczną osobą. Ona się mną zaopiekowała, wzięła do swojego oddziału.

Dalsza wypowiedź Olgi świadczy o tym, jak bardzo była lojalna wobec swojej pierwszej opiekunki. Nawet mając propozycję lepszej pracy (cały etat zamiast połowy etatu), wybrała pracę z Barbarą. W tym samym przedszkolu pracowała przez 2 lata, zrezygnowała ze względów zdrowotnych, kiedy zaszła w ciążę.

\section{Adaptacja do pracy w norweskim przedszkolu}

Przedszkola w Polsce i w Norwegii różnią się pod względem organizacyjnym, co wiąże się z odmiennym funkcjonowaniem oraz priorytetami, które wpływają na charakter 
pracy z dziećmi (Bielińska 2013; Jakubowska 2016; Parczewska 2017; Czerniejewska, Main 2019). Do przedszkoli przyjmowane są dzieci w wieku 0-5 lat. Istnieje podział na grupy dzieci młodszych (0-3 lat) oraz starszych (3-5 lat), choć część przedszkoli wybiera model grup zróżnicowanych wiekowo, zakładając, że młodsze dzieci będą uczyły się od starszych. Inna niż w większości polskich przedszkoli organizacja przestrzeni (podział na sale tematyczne) i czasu (dużo czasu przeznaczonego na swobodną zabawę, szczególnie na dworze) wpływa na rozkład dnia przedszkolaków. Pracownicy przedszkoli kładą nacisk na wartości istotne w kulturze norweskiej, takie jak samodzielność, możliwość współdecydowania, równe prawa dla wszystkich. Pracując w przedszkolach, migrantki stopniowo przyswajają te normy oraz uczą się, w jaki sposób wspierać te wartości w rozwoju dzieci.

Część norm kultury norweskiej okazuje się jednak trudna do akceptacji dla migrantek. Przedszkola, podobnie jak większość norweskich przedsiębiorstw i zakładów pracy, charakteryzują się płaską strukturą organizacyjną, brakiem hierarchii wśród pracowników. Weronika Błaszczyk podkreśla: ,polska struktura organizacyjna jest hierarchiczna, a szef jest jednostką dominującą. Decyzje podejmowane są głównie przez niego, w porównaniu do Norwegii, gdzie te decyzje podejmowane są wspólnie" (Błaszczyk 2017: 32). W takiej strukturze kierownik, a w wypadku środowiska przedszkolnego - nauczyciel prowadzący mają praktycznie takie same obowiązki jak wszyscy inni pracownicy. Kobiety deklarują, że znają tę normę kulturową, jednak w odniesieniu do własnej praktyki często mają trudności z jej akceptacją.

Z prowadzonych badań wynika, że praca w środowisku o płaskiej strukturze jest dla Polek atrakcyjna wyłącznie na początkowym etapie pracy. Marta (10 lat) była zachwycona, gdy dyrektorka witała się ze wszystkimi pracownikami „uściskami na misia”. Po jakimś czasie poczuła się jednak niekomfortowo w takim bliskim kontakcie. Na chaos i brak organizacji narzekała również jedna z nauczycielek prowadzących oddział, która nie akceptowała, że wynoszenie śmieci, praca w kuchni czy zmiana pieluch dzieciom należy do jej obowiązków w takim samym stopniu jak asystentek. Obie kobiety zaczęły sobie radzić z tą normą - unikając kontaktu fizycznego lub organizując swoją pracę w taki sposób, żeby ograniczyć konieczność gotowania posiłków.

Obydwa przykłady wskazują na silnie przekonania przeniesione z polskiego systemu pracy o tym, że instytucje lepiej funkcjonują, gdy mają strukturę hierarchiczną, a do każdej funkcji przypisane są odpowiednie obowiązki zależne od pozycji. Ta norma kulturowa znacznie utrudniała migrantkom przystosowanie się do pracy w nowym środowisku.

Niebagatelne znaczenie ma fakt, że migrantki, z którymi rozmawiałam, nie planowały powrotu do Polski. Trudności adaptacyjne, z którymi się mierzyły, traktowały jako wyzwanie, poszukując sposobów na ich zminimalizowanie. Jedną z metod wspierających je w konstruktywnym planowaniu przyszłości w Norwegii było gromadzenie pozytywnych argumentów, afirmacji sprzyjających ich decyzji o osiedlaniu się. Stąd też wiele narracji migrantek o różnicach kulturowych kończyło się często akceptacją norweskich wartości. 


\section{Różnice kulturowe w przedszkolach}

Migrantki znały polskie przedszkola $\mathrm{z}$ doświadczeń prywatnych, żadna z nich nie pracowała wcześniej w polskim przedszkolu, dwie były nauczycielkami w szkołach podstawowych. Wobec różnic w podejściu do opieki nad dziećmi w polskim i norweskim przedszkolu często odczuwały dysonans poznawczy, z którym musiały sobie radzić. Przykładem może być stosunek do prac manualnych i przygotowania do nauki czytania i pisania oraz swobodnych zabaw na świeżym powietrzu, odmiennie traktowanych w obu krajach. Marta (10 lat), która od pięciu lat pracuje w przedszkolu w okolicach Oslo, wyjaśnia, że freelek, czyli swobodna zabawa, jest kluczową ideą w norweskim przedszkolu:

Dzieci robią, co chcą, a nauczyciel chodzi dookoła. I tak naprawdę pracuje się nad tym, żeby na zewnątrz była zabawa między dorosłym a dzieckiem. Tak jest w naszym przedszkolu, takie są zalecenia dyrektorki. (...) Dorośli sobie wędrują, patrzą i bawią się z dziećmi, najczęściej w to, co dzieci zaproponują. Ale czasami, jak są dzieci, które nie mogą sobie nic znaleźć, to dorosły wtedy coś podpowiada. Wiosną to jest szukanie dżdżownic, podnosimy kamienie, wsypujemy dżdżownice do wiaderek, dzieci się bardzo z tego cieszą. Później jakieś insekty, mrówki, zbieranie kwiatków, to jest całą wiosnę. To, co dzieci chcą.

Pojęcie swobodnej zabawy, spontanicznie podejmowanej przez dzieci w wieku przedszkolnym (Brzezińska i in. 2011), jest znane pedagogom wykształconym w Polsce. Rozmówczynie jednak zauważały, że w ich kraju większy nacisk kładzie się na przygotowanie edukacyjne niż na swobodną zabawę dzieci. Katarzyna Gawlicz potwierdza, że na poziomie deklaracji polskie przedszkole dba o „wszechstronny, bezpieczny i radosny rozwój”, podczas gdy w praktyce realizowana jest koncepcja „napełniania pustego naczynia, jakim jest dziecko" (Gawlicz 2011: 272-273).

Rozmowy i obserwacje w środowisku przedszkolnym autorki niniejszego artykułu wskazują, że proces radzenia sobie z różnicami jest niezwykle istotny dla migrantek w procesie adaptacji i zakorzeniania się w kulturze norweskiej. Jest to swoiste pertraktowanie między wartościami, które znacznie wpływa na integrację. Przykładem może być Ewa (1,5 roku), która zna polskie przedszkole z perspektywy rodzica:

W Polsce podobał mi się poziom nauczania i to, że dzieci są zajęte, mają dużo zajęć, wszyscy muszą usiąść przy stolikach i rysować, malować. To też jest dobre momentami, bo ja mam takie dzieci [tutaj w Norwegii], które nigdy nie miały okazji, żeby usiąść i porysować.

Z kolei Marta (10 lat) zauważa, że „w Polsce jest tego [rysowania, pracy przy stolikach] trochę za dużo". W zależności od przekonań Polki mogą odczuwać większy lub mniejszy dyskomfort z wykonywanej pracy, mogą się zgadzać z takim podejściem lub mu się sprzeciwiać. Niemniej ewolucja refleksji nad tymi zasadami i wartościami znacznie je ubogaca. 
Proces rozumienia różnic odbywa się etapami. Na początku dostrzegają one rozbieżności w sposobach postępowania i stojących za nimi odmiennych ideach, np. dzieci powinny dużo rysować i wycinać, w ten sposób ćwiczą małą motorykę, vs. dzieci powinny bawić się swobodnie. Następnie pojawia się refleksja skłaniająca do myślenia nad zasadnością stosowania jednego lub drugiego podejścia. Zestawienie obu idei kończy się oceną i podjęciem działań zgodnie $\mathrm{z}$ wybranymi założeniami lub próbą połączenia obu - trochę porysujemy, a później wyjdziemy na zewnątrz. Trzeba przyznać, że w tych negocjacjach rozmówczynie korzystały $\mathrm{z}$ własnych doświadczeń pracy z dziećmi $\mathrm{w}$ środowisku polskim i norweskim, jednak punktem odniesienia była ich wiedza na temat rozwoju i potrzeb konkretnych dzieci. Tym, co najczęściej umacniało ich decyzje, był pozytywny skutek w rozwoju dziecka. Ponadto znajomość obu, niekiedy skrajnych, podejść do sposobu pracy przedszkolnej miała wpływ na ich bardziej wyważony stosunek do zadań pracowniczek przedszkoli. Kobiety nie podejmowały decyzji automatycznie, motorem ich działań były refleksje nad zasadnością różnych metod pracy.

W każdym norweskim przedszkolu dzieci spędzają na dworze co najmniej dwie godziny dziennie, w niektórych placówkach nawet 4-5 godzin. Polki najczęściej pozytywnie oceniały to norweskie podejście. Ewa (1,5 roku) mówi:

Ja doceniam to, że oni dużo czasu spędzają na dworze, bo ja się nie mogłam doprosić w polskim przedszkolu, żeby oni trochę więcej byli na dworze. Zazwyczaj było to siedzenie w murach i piłowanie piosenek.

Jednak przebywanie zbyt długo na zewnątrz było też krytykowane, szczególnie gdy może być niekorzystne dla dziecka. Beata (3 lata), odpowiedzialna za oddział 20 dzieci, w którym ponad połowę stanowią dzieci imigrantów z Pakistanu, Iraku, Iranu, podkreśla, że dla tej grupy swobodne zabawy na zewnątrz są niekorzystne ze względu na braki językowe i edukacyjne tych dzieci, które w nieodległym czasie mają rozpocząć szkołę:

Ja walczę z tym, żeby dzieci były cały dzień na dworze. (...). Rodzice wysyłają takiego 4-latka do przedszkola, żeby się języka nauczył, zanim pójdzie do szkoły. Trudno się nauczyć, jak one są na dworze. To jest tragedia, zaraz ma iść do szkoły, a język na poziomie 3-latka.

Warto podkreślić, że proces dostosowywania się do norm i nabywania kompetencji przez pracownice przedszkola jest ciągły. Rozmówczynie przyznawały, że w trakcie pobytu i pracy w Norwegii zmieniały swój stosunek do pewnych rozwiązań, a niekiedy łagodziły swoje stanowisko. Dzięki możliwości ponownej rozmowy z tymi samymi badanymi po roku miałam okazję obserwować ewolucję ich przekonań zawodowych. Beata (3 lata) przyznała, że zrewidowała swoje oceny pewnych zasad panujących w przedszkolu. Podczas naszego pierwszego spotkania żaliła się na ubogie materiały plastyczne w wyposażeniu przedszkola, w którym pracowała. Podczas kolejnej rozmowy twierdziła już inaczej: 
Jest wiele rzeczy, które mnie [w norweskim przedszkolu] wcześniej denerwowały, że nie ma ciepłego jedzenia, że jest tylko jednokolorowa plastelina... natomiast to, w jaki sposób się podchodzi do tych dzieciaków, to jest większą wartością niż kolorowa plastelina i żeby były superowskie kredki i świetne zabawki. Bardzo mocno mi się to poprzestawiało. Widzę duży wkład ludzi, którzy tam pracują w budowanie relacji z dzieciakami. To są fajne rzeczy, rozmawianie z dziećmi, bycie z nimi.

Refleksja nad odmiennym podejściem do pracy z dziećmi jest wywołana sytuacją migracji z Polski. Kobiety wybierają, negocjują spośród wartości obu krajów, dostosowując je do danej sytuacji, równocześnie mają własne przemyślenia nad zastanymi normami i same przystosowują się do nich, coraz lepiej je rozumiejąc.

\section{Sposób na zakotwiczenie się}

Z rozmów z migrantkami wynika, że ważnym czynnikiem, który uzasadniał ich pracę w norweskim przedszkolu, szczególnie w początkowym okresie pracy, było przekonanie, że ich praca jest użyteczna społecznie, potrzebna społeczności lokalnej, a one same posiadają kompetencje, dzięki którym mogą się stać częścią norweskiego społeczeństwa. Takie podejście wytwarzało silną relację łączącą migrantki z ich nowym miejscem życia, nawiązującą do koncepcji społecznego zakotwiczania migrantów w nowym środowisku (Grzymała-Kazłowska 2013). Autorka definiuje zakotwiczanie jako: „,poszukiwanie przez migrantów istotnych dla nich punktów odniesienia i oparcia - kotwic, które pozwalają im osiągnąć relatywną psychospołeczną stabilność w nowej sytuacji życiowej" (Grzymała-Kazłowska 2013: 53).

Podczas wywiadów kobiety wyjaśniały szczegóły swojej pracy, proces przystosowywania się do nowego środowiska, przekonując mnie o swojej przydatności, co dodatkowo ugruntowywało je w norweskim społeczeństwie. Olga (4 lata) mówiła o początkach swojej pracy w przedszkolu w ten sposób:

Ja dawałam z siebie wszystko, $150 \%$, było fajnie, oni byli zadowoleni. Powiedzieli mi, że nie muszę się aż tak starać, że mogę sobie czasami siąść. Dawało mi to straszną satysfakcję. Ja chciałam tam być dłużej, jak już kończyłam i miałam iść do domu, to nie chciałam. Zawsze wychodziłam niechętnie.

Katarzyna (8 lat) swoją moc czerpała z bliskiego kontaktu z dziećmi. To dawało jej odpowiedź na pytanie, dlaczego czuje się potrzebna w przedszkolu - skoro dzieci ją polubiły, to oznacza, że tu jest jej miejsce.

Za każdym razem, jak ja wychodziłam do domu, to dzieci płakały, więc (...) [nauczyciel prowadzący pytał dzieci]: ale co jest? czemu? i na okrągło było: gdzie jest Kasia? gdzie jest Kasia? gdzie jest Kasia? I tak zostałam. Jestem jak mama. Dzieci siedzą na kolanach, przytulają się, a tam trochę tego brakowało. To był taki trochę zimny wychów. 
Anna (4 lata) była bardzo dumna ze swojej pracy, z zajęć, które udało jej się wprowadzić do przedszkola. Z przekonaniem mówiła, że najważniejsze dla niej to „robić swoje”:

Zaczęłam rysować, bo czułam, że z dziećmi można robić mnóstwo kreatywnych rzeczy (...). I poczułam, że to jest mój sukces. I kiedyś na jakiejś rozmowie z [jej nauczycielką prowadzącą] mówię, że jestem jej tak wdzięczna, a ona mówi - my też jesteśmy tobie wdzięczni, zobacz jak to przedszkole się zmienia dzięki temu, że jesteś.

Olga, Katarzyna i Anna tworzyły więzi z Norwegią przez sumienne wykonywanie pracy w przedszkolu, korzystały z własnych pokładów cierpliwości, twórczości i dobrych relacji z dziećmi. Indywidualne zasoby kobiet w sytuacji migracji je wzmocniły, pozytywnie wpłynęły na poczucie własnego sprawstwa, wzrost pewności siebie, co w rezultacie przyczyniło się do łatwiejszego dopasowywania się do społeczeństwa norweskiego. Narracja o korzyściach, jakie społeczeństwo norweskie odnosi dzięki ich zaangażowaniu w pracę, była często podnoszonym się argumentem, stąd wnioskuję, że ta pobudka jest dla nich szczególnie istotna w osiągnięciu dobrostanu w nowym kraju.

\section{Zakończenie}

Badania przeprowadzone wśród migrantek deklarujących chęć pozostania w Norwegii przybliżają sposoby przystosowywania się kobiet do pracy w przedszkolach. Jednak niewielka próba badawcza oraz ograniczenia czasowe (2 lata) nie pozwalają na udzielenie odpowiedzi na wszystkie pytania, które mogą być istotne dla zgłębienia tematu adaptacji migrantek w nowym środowisku.

Migrantki stosują różne kotwice, by przywiązać się do nowego kraju. Poczucie przydatności, wyraźne w ich narracjach, jest tylko jedną z nich. Innymi aspektami zakotwiczania się w społeczeństwie norweskim są m.in. posiadanie stałej pracy, zadowalające wynagrodzenie, uzyskanie kredytu na mieszkanie, opanowywanie języka na coraz wyższym poziomie, tworzenie własnych sieci społecznych. Wszystkie te elementy równolegle na siebie oddziałują, wpływają na lepsze samopoczucie i uzasadniają decyzję o migracji do Norwegii. Zbadanie korelacji pomiędzy różnymi czynnikami wpływającymi na lepszą adaptację w nowym kraju mogłyby być tematem dalszych badań.

W kolejnych analizach warto również dokładniej przyjrzeć się procesowi rozumienia różnic kulturowych, negocjowania między wartościami - tutaj te zagadnienia zostały zaledwie zasygnalizowane. Być może dobrze wypracowane mechanizmy radzenia sobie z różnicami kulturowymi są kolejnym czynnikiem wspierającym zakotwiczanie się migrantek.

\section{Literatura}

Bell J., Erdal M.B. (2015), Limited but enduring transnational ties? Transnational family life among Polish migrants in Norway. „Studia Migracyjne - Przeglad Polonijny”, 41(3).

Bielińska I. (2013), Dziecko w przedszkolu w Polsce i Norwegii (z zajęciami ruchowymi w tle). „Problemy Wczesnej Edukacji”, 1(20). 
Błaszczyk W. (2017), Czynniki negatywne, utrudniające budowanie pozytywnych relacji w zespole na podstawie porównania polskich i norweskich przedsiębiorstw. „Współczesne Wyzwania Zarządzania", 28.

Brzezińska A.I. i in. (2011), O roli zabawy w przygotowaniu dziecka do dorosłego życia. „Wychowanie w Przedszkolu", 10.

Czapka E. (2010), The Health of Polish labour immigrants in Norway. Oslo, Norwegian Center for Minority Health Research.

Czerniejewska I., Main I. (2019), Projektowanie dziecka w społeczeństwie norweskim. Matki z Polski wobec instytucji przedszkola. „Studia Migracyjne - Przegląd Polonijny”, 1(171).

Friberg J.H. (2012), The stages of migration. From going abroad to settling down: post-accession Polish migrant workers in Norway. „Journal of Ethnic and Migration Studies”, 38(10).

Gawlicz K. (2011), Różowe koty. Spanie na prawym boku i piła w przedszkolu. Dyskursywne konstrukcje dziecka i dzieciństwa a polskie i skandynawskie praktyki pedagogiczne. W: D. Klus-Stańska, D. Bronk, A. Malenda (red.), Pedagogika wczesnej edukacji. Dyskursy, problemy otwarcia. Warszawa, Wydawnictwo Akademickie Żak.

Gmaj K. (2016), Settling in Norway? The case of Polish migrants and their families. „Myśl Ekonomiczna i Polityczna", 2(53).

Gmaj K. (2018), Inspired by Thomas and Znaniecki. Do We Observe the Formation of a New PolishNorwegian Society. „Sociology”, 8(3).

Grabowska-Lusińska I., Okólski M. (2009), Emigracja ostatnia? Warszawa, Scholar.

Grzymała-KazłowskaA. (2013), Zarys koncepcji społecznego zakotwiczenia. Inne spojrzenie na tożsamość, adaptację i integrację imigrantów. „Kultura i Społeczeństwo”, 3.

Huang L., Krzaklewska E., Pustulka P. (2016), Young Polish migrants in Norway: education, work and settlement choice. ,Tidsskrift for Ungdomsforskning”, 16(1).

Jakubowska K. (2016), Gdy spotykają się różne kultury. Oblicza dzieciństwa na emigracji na przykładzie Norwegii. „Problemy Wczesnej Edukacji”, 4(35).

Napierała J. (2008), Imigranci na norweskim rynku pracy. „CMR Working Papers”, 31(89).

Napierała J., Trevena P. (2010), Patterns and determinants of sub-regional migration: a case study of Polish construction workers in Norway. W: R. Black, G. Engbersen, M. Okólski (ed.), A continent moving West? EU enlargement and labour migration from Central and Eastern Europe. Amsterdam, Amsterdam University Press.

Parczewska T. (2017), W stronę przyrody: o norweskich praktykach edukacji na zewnatrz. „Zeszyty Naukowe Wyższej Szkoły Humanitas. Pedagogika", 15.

Pawlak M. (2015), Recognizing the national identity: cultural intimacy and the Polish migration to Norway. „Zeszyty Naukowe Uniwersytetu Jagiellońskiego. Prace Etnograficzne”, 43(3).

Pawlak M. (2016), Zaufanie, wzajemność, nieufność. Mobilna pragmatyka życia polskich migrantów w Norwegii. „Studia Migracyjne - Przeglad Polonijny”, 2(160).

Slany K., Strzemecka S. (2015), Gender roles and practices in Polish migration families in Norway through the eyes of children. „Studia Migracyjne - Przeglad Polonijny”, 3.

Strzemecka S. (2015), School integration in the eyes of migrant children. Based on the Polish migration to Norway. „Przegląd Socjologiczny”, 64(1).

Ślusarczyk M., Nikielska-Sekuła K. (2014), Między domem a szkoła. Dzieci migrantów w systemie edukacyjnym. Kontekst norweski. „Studia Migracyjne - Przeglad Polonijny”, 2(152).

Ślusarczyk M., Pustułka P. (2016), Norwegian schooling in the eyes of Polish parents: from contestations to embracing the system. „Central and Eastern European Migration Review”, 5(1). 